\title{
THE ABILITY OF MATHEMATICS TEACHERS IN USING COMPUTERS, SMARTPHONES, AND INTERNET
}

\author{
In In Supianti ${ }^{1}$, Acep Saeful Malik ${ }^{2}$, Anggit Sagita ${ }^{3}$ \\ ${ }^{1}$ Universitas Pasundan, ${ }^{2}$ SMKN Peternakan Lembang, ${ }^{3}$ SMAN 3 Garut \\ supianti@unpas.ac.id, acepsaefulmalik@gmail.com, anggitmatematika@gmail.com
}

\begin{abstract}
ABSTRAK
Tujuan penelitian ini adalah mengetahui kemampuan guru matematika dalam menggunakan komputer, smartphone, dan internet berdasarkan jenjang tahun lahir (generasi) dan gender. Kemampuan guru dalam menggunakan komputer, smartphone, dan internet sangat berguna untuk menunjang dalam pembelajaran matematika menggunakan teknologi informasi dan komunikasi terutama pada situasi pandemi Covid-19 ini. Hasil penelitian ini dapat digunakan untuk memetakan guru matematika di tiap sekolah dan menetapkan model pembelajaran terbaik agar pembelajaran dapat terlaksana dengan baik dan optimal. Metode penelitian yang digunakan adalah penelitian kualitatif, dengan melakukan survey terhadap 92 orang guru matematika yang terdiri dari 35 orang guru SMP dan 57 orang guru SMA di Jawa Barat. Hasil penelitian menunjukkan bahwa: (1) kemampuan guru matematika dalam menggunakan komputer, smartphone, dan internet sudah menunjang dalam penerapan pembelajaran berbasis teknologi dalam pembelajaran matematika; (2) terdapat perbedaan kemampuan menggunakan komputer, smartphone, dan internet antara guru matematika generasi X, Y, dan Z. Kemampuan menggunakan komputer, smartphone, dan internet guru matematika generasi $\mathrm{Y}$ dan $\mathrm{Z}$ lebih baik daripada generasi $\mathrm{X}$; (3) terdapat perbedaan kemampuan menggunakan komputer, smartphone, dan internet antara guru laki-laki dan perempuan. Guru laki-laki lebih baik daripada guru perempuan; (4) tidak terdapat perbedaan yang signifikan kemampuan menggunakan komputer, smartphone, dan internet antara guru matematika pada jenjang SMA dan SMP; (5) tidak terdapat efek interaksi antara generasi dan jenjang pendidikan terhadap pencapaian kemampuan menggunakan komputer, smartphone, dan internet.
\end{abstract}

Kata Kunci : E-learning, Mobile Learning, Teknologi Informasi dan Komunikasi.

\begin{abstract}
This study aimed to determine the ability of mathematics teachers to use computers, smartphones, and the internet according to their birth years (generation) and gender. The ability of teachers to use computers, smartphones, and the internet is beneficial to support mathematics learning using information and communication technologies especially in this Covid-19 pandemic situation. The results of this study can be used to map mathematics teachers in each school and determine the best learning model so that learning can be cariied out properly and optimally. The research method was mixed research by surveying 92 mathematics teachers, 35 junior high school mathematics teachers, and 57 high school mathematics teachers in West Java. The results show that: (1) the ability of mathematics teachers in using computers, smartphones, and the internet has supported the application of technology-based learning in mathematics learning; (2) there are differences in the ability to use computers, smartphones, and the internet among the $\mathrm{X}, \mathrm{Y}$ and $\mathrm{Z}$ generation of mathematics teachers. The ability in using computers, smartphones, and the internet of the $\mathrm{Y}$ and $\mathrm{Z}$ generation of mathematics teachers is better than that the of $X$ generation; (3) there are differences in the ability in using computers, smartphones, and the internet between male and female teachers; male teachers are better than female teachers; (4) there is no significant difference in the ability in using computers, smartphones and internet between mathematics teachers at the high school and junior high school
\end{abstract}


levels; (5) there is no interaction effect between teacher generations and levels of educational institution, on their achievement of the abilities in using computers, smartphones, and the internet.

Keywords: E-learning, Mobile Learning, Information and Communication Technology

\section{INTRODUCTION}

The very fast-moving development of technology and information has affected students' character, motivation, participation, and learning styles. The generation of students born with digital technology has significant characteristics in their learning approaches; they are accustomed to having access to information resources easily and quickly. The development of technology and mathematics are interrelated. Developments in mathematical structure and reasoning in number theory, algebra, analysis, probability theory, and discrete mathematics can often be applied to technological development (Dirgantoro, 2018). According to Taleb, Ahmadi, \& Musavi (2015) and Kapustina, Popyrin, \& Savina (2015), also Valeev, Latypova, \& Latypov (2016), technology can increase students motivation and participation in learning mathematics. Accordingly, Abdussakir (2013) stated that technology in learning could (1) increase students' attention and concentration on the learning material; (2) increase learning motivation; (3) adjust the material to the students' learning abilities; (4) reduce the material delivery time; (5) make the learning experience more enjoyable. Learning applications motivate the students, make mathematics more fun and interactive than ordinary learning (Drigas \& Pappas, 2015). For this reason, teachers are required to master technology to use it in developing learning materials and media and improving the quality of education in Indonesia, so the students are expected to be able to face and compete in the era of industrial revolution 4.0 and society 5.0.

Various technologies and applications have been developed to support and assist teaching and learning activities in education. These applications include Zoom Meeting, YouTube, Google Classroom, Home Learning, Teacher's Room, Google Forms, Moodle, and many other applications. Zoom Meeting is an application of communication using video; in this case, teachers and students can interact through video using laptops or smartphones connected to the internet so that the learning process can take place anytime, anywhere. Teachers can also make live video lessons of learning or mathematical presentations when teaching through the YouTube channel. In assignments and evaluations, teachers can give assignments directly to students by using the Learning House application, Teacher's Room, Google Classroom, and Google Form. The applications can be used with computer and smartphone media connected to the internet. Applications designed explicitly for 
mathematical materials include GeoGebra, Sketchpad Geometers, Cabry, Maple, Math plus, Photomath, and many other applications. Alkhateeb \& Al-Duwairi's research results (2019) showed that Sketchpad and GeoGebra facilitate understanding geometrical concepts. In addition, the TPACK model has also been designed, which is a frame of reference that enables to create of an active strategy for teaching and learning through the use of ICTs (Chua \& Jamil, 2014; Ozudogru \& Ozudogru, 2019; Salas-Rueda, 2019)

Asmaranti \& Andayani's research results (2018) showed that: (1) according to the perspective of the teacher learning mathematics with computer-based learning media is essential to do; (2) school facilities, infrastructure, and teachers' competencies to support computer-based learning are sufficient; (3) the teachers are very interested in applying mathematics learning using interactive and engaging computer-based media; (4) students are more interested in computer-based learning media than in using textbooks; (5) various potentials are originating from students who can support the use of computers as a source of student learning, such as ownership of a computer/ laptop, the ability to operate the computer/ laptop, accustomed to using the computer/ laptop as a source of learning, and the duration of computer use in daily activities are high enough. Supianti, Wahyudin, Kartasasmita, \& Nurlaelah's research (2018) showed that according to the information from 258 students, in the number of mathematics teachers in West Java, 50.8\% had often, $45 \%$ had, and 4.2\% had never applied ICT in Mathematics learning. The most common form of applying ICTs in mathematics learning is to assign students to search for materials from the internet. Out of the 258 students, $12 \%$ stated that it was necessary, $55 \%$ said it was required, and $12 \%$ said it was unnecessary to apply ICT in Mathematics learning. According to 56 mathematics teachers, $45 \%$ had often, $54 \%$ had, and 1\% had never applied ICT in learning mathematics (Supianti, Wahyudin, Kartasasmita, \& Nurlaelah, 2018b)

There are many benefits to use ICT in learning, including (1) facilitating the search for knowledge; (2) saving time; (3) saving cost; (4) facilitating and speeding up to obtain reference materials for teaching; (5) facilitating the work; (6) becoming an effective and efficient online communication tool, both domestically and abroad; (7) making easy to access information; (8) broadening horizons; (9) making easy to present and deliver the learning materials; (10) making easy for students to understand the materials; (11) training the independence of student learning (Supianti, 2018). As is the case today, the Coronavirus pandemic (Covid-19). The existence of the coronavirus pandemic impacts almost all important sectors in Indonesia, especially his education. Enforcement of physical distancing 
policy to prevent the spread of Covid-19 virus then becomes the basis for implementing learning from home, using information and communication technology. It becomes a challenge for teachers to be able to use the information and communication technology in learning activities as well

Teachers, as implementers and facilitators of learning, play a very important role in learning. The successful integration of ICT in learning is a strategic role assumed by the teacher (Marzal, 2013). The success of ICT implementation is determined by dynamic processes that involve a set of interrelated factors. In developed countries, the ability of teachers in ICTs has been developed since 1998. Teachers are an essential part of a curriculum and have a significant impact on student learning (Marzal, 2013). The application of information and communication technology in mathematics learning must be supported by technology-based learning facilities. In addition, educators and students have also been equipped with knowledge about technology and mathematics learning media. The ability of ICT has classified the ability to use computers, smartphones, and the internet.

Computers and smartphones are tools that can interact quickly and accurately, work quickly and precisely, and store large and safe amounts of data. Clements (Abdussakir, 2013) stated that computers are media that can be used to (1) increase students' attention and concentration in learning a subject, (2) increase students' motivation to learn, (3) adapt the material to students' learning abilities, (4) reduce the use of time to deliver material, and (5) make the learning experience more enjoyable for students. Moyer in (Wibowo, Wahyu; Haryatmi, Sri; Budiantara, 2009) stated that the internet as an unlimited learning resource provides various applications that enable interaction with other internet users, both interpersonal and mass. These explanations of the function of the internet are a source of learning, and media in teaching and learning activities can be carried out massively.

Mobile devices are cheaper than personal computers and are used by many people because they are more affordable, and in this case, most people have them. Therefore, elearning is possible through the use of mobile phones to obtain information or for learning purposes. Recent developments in cellular and wireless technology have facilitated this new learning model, m-learning (Taleb \& Sohrabi, 2012). Educational applications for mobile devices motivate students and attract their attention while focusing on problem-solving, improving memory, reading, and writing skills. In addition to the traditional classroom context, the use of advanced technology in the learning process and assessment through mlearning enables students to develop usage time according to their needs, with their 
experiences (Saleh and Alias, 2012). M-learning is liked by students because it is equipped with features and is interactive. It provides a stress-free environment that is user-friendly. The design and layout of the text can eliminate frustration and confusion while making source information much easier to be explicitly received in some subjects such as Mathematics (Skiada, Soroniati, Gardeli \& Zissis, 2013).

The purpose of this study is to find out how the ability of mathematics teachers to use computers, smartphones, and the internet in terms of levels of education in the place of teaching, gender, and year of birth of the teacher (generation). The research questions are (1) Does the ability of mathematics teachers in using computers, smartphones, and the internet support the application of technology-based learning in mathematics learning; (2) How the ability of mathematics teachers in using computers, smartphones, and the internet is evaluated from the education level of the teaching place, gender and year of birth of the teacher (generation)

\section{RESEARCH METHOD}

This research is survey research with a questionnaire independent test on the ability of mathematics teachers to use computers, smartphones, and the internet. The questionnaire was given to mathematics teachers in West Java who completed a Master in degrees Mathematics Education study program at the Postgraduate Studies Program of Pasundan University. The sample was 35 junior high school mathematics teachers and 57 high school mathematics teachers in West Java. Samples were taken based on random sampling technique. The distribution of teachers came from the city and regency of Bandung, West Bandung Regency, Sumedang, Karawang, Cianjur, West Bandung, Garut Regency, Subang, City and Cirebon District, Indramayu, Banjar, Tanjungpinang. Majalengka, Kota and district of Sukabumi, Bekasi, Bogor Regency. The 21 mathematics teachers were from Generation $\mathrm{X}$ (born in 1961-1980), 42 teachers were from Generation $\mathrm{Y}$ or the millennial generation (born in the period 1981-1994), and 29 teachers were from Generation Z (born in the years 1995-2010). The mathematics teachers were 60 female and 32 male, as shown in Table 1 below.

Table 1. Distribution of Samples

\begin{tabular}{lcccccc}
\hline & \multicolumn{3}{c}{ Generation } & \multicolumn{2}{c}{ Gender } & \multirow{2}{*}{ Total } \\
\cline { 2 - 5 } & $\mathrm{X}$ & $\mathrm{Y}$ & $\mathrm{Z}$ & Male & Female & \\
\hline MiddleSchool & 13 & 17 & 5 & 25 & 10 & 35 \\
High School & 8 & 25 & 24 & 35 & 22 & 57 \\
Total & 21 & 42 & 29 & 60 & 32 & 92 \\
\hline
\end{tabular}


The research instrument used was a self-test questionnaire on the ability of mathematics teachers to use computers, smartphones, and the internet. The questionnaire consisted of 40 statements consisting of 17 statements regarding the ability to use computers, four statements regarding the ability to use smartphones, and 19 statements regarding the ability to use the internet. The questionnaire was made in a Google Form, then distributed and filled in online by respondents. The questionnaire was tested first on 10 teachers with the results that all statement were valid and reliable with score of Cronbach's Alpha 0,775. The results of the questionnaire were analyzed with the ANOVA 2-way Test to determine differences in the ability of mathematics teachers in using computers, smartphones, and the internet, based on the level of education in the place of teaching, generation, and gender of the teachers.

\section{RESULT AND DISCUSSION}

The results of the questionnaire on the ability of mathematics teachers in using computers, smartphones, and the internet, which are presented based on the level of education in the place of teaching and the year of birth (generation) of teachers, are shown in Table 2. in Table 2 it can be seen that the percentage of the number of high school teachers much more than generation $\mathrm{Y}$ and $\mathrm{Z}$, but the difference between generation $\mathrm{Z}$ and $\mathrm{Y}$ was not significantly different (1.04), but with generation X was much different (28.33). Likewise, among high school teachers, it can be seen, from the data above that the average junior high school teachers who chose the good category in generation $\mathrm{Z}$ were more numerous than the generation $\mathrm{Y}$ and $\mathrm{Z}$. The difference between generation $\mathrm{Z}$ and $\mathrm{Y}$ was (4.18), but with generation X, was much different $(27,41)$. Overall, the ability of both mathematics teachers and high school teachers was good; in all generations, the good criteria more than $50 \%$.

Table 2. Results of the questionnaire on the ability in using computers, smartphones, and the internet based on Level of Education and Generation

\begin{tabular}{|c|c|c|c|c|}
\hline Level of Education & Generation & Criteria & Total & $\%$ \\
\hline \multirow{9}{*}{ High School } & \multirow{3}{*}{$\mathrm{X}$} & Good & 172 & 53,75 \\
\hline & & Sufficient & 134 & 41,88 \\
\hline & & Less & 14 & 4,38 \\
\hline & \multirow{4}{*}{ Y } & Good & 808 & 81,04 \\
\hline & & Sufficient & 179 & 17,95 \\
\hline & & Less & 10 & 1,00 \\
\hline & & Good & 788 & 82,08 \\
\hline & \multirow{2}{*}{$\mathrm{Z}$} & Sufficient & 149 & 15,52 \\
\hline & & Less & 23 & 2,40 \\
\hline \multirow{8}{*}{ Middle School } & \multirow{5}{*}{$\mathrm{X}$} & Good & 292 & 56,59 \\
\hline & & Sufficient & 211 & 40,89 \\
\hline & & Less & 13 & 2,52 \\
\hline & & Good & 542 & 79,82 \\
\hline & & Sufficient & 123 & 18,11 \\
\hline & \multirow{3}{*}{ Y } & Less & 14 & 2,06 \\
\hline & & Good & 168 & 84,00 \\
\hline & & 24 & & \\
\hline
\end{tabular}




\begin{tabular}{|c|c|c|c|c|}
\hline & $\mathrm{Z}$ & $\begin{array}{l}\text { Sufficient } \\
\text { Less }\end{array}$ & $\begin{array}{c}27 \\
5\end{array}$ & $\begin{array}{c}13,50 \\
2,50\end{array}$ \\
\hline Information: & $\begin{array}{l}\text { Generation X: Born } \\
\text { Generation Y: Born } \\
\text { Generation Z: Born }\end{array}$ & $\begin{array}{l}\text { ears 1961-1980 } \\
\text { ears 1981-1994 } \\
\text { ears } 1995-2010\end{array}$ & & \\
\hline
\end{tabular}

To find out in more detail what abilities that math teachers already had, an analysis was carried out based on three categories of teachers' ability in using ICT, namely the ability of teachers in using laptops, the ability of teachers in using smartphones, and the ability of teachers in using the internet presented in Table 3. Table 3 shows that the $\mathrm{X}$ generation high school mathematics teacher had better ability in using laptops and smartphones than using the internet. Among the Y generation high school mathematics teachers, the ability to use a laptop and smartphone was very good (more than 85\%), and the ability to use the internet was good $(72.21 \%)$. The high school mathematics teachers of generation $\mathrm{Z}$ were not much different from generation Y. The conclusions for junior high school mathematics teachers were not much different from the conclusions for high school mathematics teachers.

Table 3. Results of the questionnaire on the ability in using computers, smartphones, and the internet based on gender

\begin{tabular}{|c|c|c|c|c|c|c|c|c|}
\hline Level & Generation & Category & \multicolumn{2}{|c|}{ Computer } & \multicolumn{2}{|c|}{ Smartphone } & \multicolumn{2}{|c|}{ Internet } \\
\hline \multirow{7}{*}{ High School } & \multirow{3}{*}{$\mathrm{X}$} & Good & 93 & 68,38 & 20 & 62,50 & 59 & 38,82 \\
\hline & & Sufficient & 43 & 31,62 & 11 & 34,38 & 80 & 52,63 \\
\hline & & Less & 0 & 0,00 & 1 & 3,13 & 13 & 8,55 \\
\hline & \multirow{3}{*}{$\mathrm{Y}$} & Good & 371 & 87,91 & 94 & 94,00 & 343 & 72,21 \\
\hline & & Sufficient & 51 & 12,09 & 6 & 6,00 & 122 & 25,68 \\
\hline & & Less & 0 & 0,00 & 0 & 0,00 & 10 & 2,11 \\
\hline & $\mathrm{Z}$ & Less & 0 & 0,00 & 0 & 0,00 & 23 & 5,04 \\
\hline \multirow{5}{*}{$\begin{array}{l}\text { Middle } \\
\text { School }\end{array}$} & \multirow{3}{*}{$X$} & Good & 130 & 59,91 & 35 & 67,31 & 127 & 51,42 \\
\hline & & Sufficient & 87 & 40,09 & 17 & 32,69 & 107 & 43,32 \\
\hline & & Less & 0 & 0,00 & 0 & 0,00 & 13 & 5,26 \\
\hline & $\mathrm{Y}$ & Good & 250 & 86,81 & 63 & 92,65 & 229 & 70,90 \\
\hline & $\mathrm{Z}$ & Less & 0 & 0,00 & 0 & 0,00 & 5 & 5,26 \\
\hline
\end{tabular}

To find out the significant difference between the ability in using computers, smartphones, and the internet among X, Y, Z generation high school teachers and among X, $\mathrm{Y}, \mathrm{Z}$ generation junior high school mathematics teachers, a 2-way Anova Test was conducted, the results of which were listed in Table 4 below.

Table 4. Anova 2 path results

\begin{tabular}{|c|c|c|c|c|c|}
\hline Source & $\begin{array}{l}\text { Type III Sum of } \\
\text { Squares }\end{array}$ & Df & Mean Square & $\mathrm{F}$ & Sig. \\
\hline Corrected Model & $2009,537^{\mathrm{a}}$ & 5 & 401,907 & 4,349 & 001 \\
\hline Intercept & 774567,728 & 1 & 774567,728 & 8382,116 & 000 \\
\hline General & 1849,598 & 2 & 924,799 & 10,008 & ,000 \\
\hline Jenjang & 3,256 & 1 & 3,256 & ,035 & 852 \\
\hline Generasi * Jenjang & 18,232 & 2 & 9,116 & ,099 & ,906 \\
\hline Error & 7947,017 & 86 & 92,407 & & \\
\hline
\end{tabular}




\begin{tabular}{lrr} 
Total & 1106281,000 & 92 \\
Corrected Total & 9956,554 & 91 \\
\hline
\end{tabular}

a. R Squared = ,202 (Adjusted R Squared $=, 155$ )

In Table 4, it can be seen that the Sig. in the "generation" line was 0,000 smaller than the significance level (0.05), meaning that there are differences in the ability in using computers, smartphones, and the internet between mathematics teachers generation $\mathrm{X}, \mathrm{Y}$, and Z. The Sig. in the "level" line was 0.852 greater than 0.05 which means there is no significant difference in the ability in using computers, smartphones, and the internet between mathematics teachers at the high school and at the junior high levels. The Sig. on the line "Generation * Level" was 0.906 , greater than 0.05 , meaning that there is no interaction effect between generations and levels of education on the achievement of the ability in using computers, smartphones, and the internet.

To find out what groups of teachers are better at using computers, smartphones, and the internet, Tukey's HSD test was continued with the results shown in Table 5 below.

Table 5. Tukey's HSD Results

\begin{tabular}{lrrrr}
\hline \multirow{2}{*}{ General } & \multirow{2}{*}{$\mathrm{N}$} & \multicolumn{3}{c}{ Subset } \\
\cline { 3 - 5 } \cline { 3 - 4 } Generasi X & 21 & 100,62 & 2 \\
Generasi Y & 42 & & 111,48 \\
Generasi Z & 29 & & 112,00 \\
Sig. & & & 1,000 &, 977 \\
\hline
\end{tabular}

From table 5 shows that in the subset column (consisting of 1 and 2), column 1 contains the average of generation $\mathrm{X}$ is 100.62 , and column 2 contains the average of generation $\mathrm{Y}$ and $\mathrm{Z}$ (111.48 and 112.00). It can be concluded that the generation of mathematics teachers generation $\mathrm{X}$ ability in using computers, smartphones, and the internet is significantly different from the $\mathrm{Y}$ and $\mathrm{Z}$ generations. In contrast, the ability to use computers, smartphones, and the internet of mathematics teachers of $\mathrm{Y}$ and $\mathrm{Z}$ generations is not significantly different. Judging from the averages, it is known that the ability to use computers, smartphones, and the internet of $\mathrm{Y}$ and $\mathrm{Z}$ math teachers is better than generation $\mathrm{X}$.

The results of the mathematics teacher's ability questionnaire in using computers, smartphones, and the internet, which were presented based on the education level of the teaching places and sex of the teachers, are shown in Table 6. In Table 6, it appears that the percentages of the mathematics teachers' ability in using computers, smartphones, and the internet of senior high school mathematics teachers are better than of the junior high school mathematics teachers; also, the male teachers are better than the women teachers. 
Table 6. Results of the questionnaire on the ability in using computers, smartphones, and the internet based on the level of education in which to teach and gender

\begin{tabular}{lllrr}
\hline Level & Gender & Category & Total & $\%$ \\
\hline \multirow{3}{*}{ High School } & \multirow{2}{*}{ Male } & Good & 754 & 90,55 \\
& & Sufficient & 110 & 8,81 \\
& & Less & 16 & 0,64 \\
\cline { 3 - 6 } & \multirow{3}{*}{ Female } & Good & 1014 & 80,48 \\
& & Sufficient & 352 & 18,62 \\
& \multirow{3}{*}{ Male } & Less & 34 & 0,90 \\
\hline & & Good & 323 & 86,83 \\
& & Sufficient & 70 & 12,54 \\
& & Less & 7 & 0,63 \\
\hline \multirow{3}{*}{ Middle School } & Good & 679 & 76,90 \\
& \multirow{2}{*}{ Female } & Sufficient & 291 & 21,97 \\
& & Less & 30 & 1,13 \\
\hline
\end{tabular}

The questionnaire data were then analyzed based on three categories, namely the ability of teachers to use laptops, in using smartphones, and in using the internet are presented in Table 7 below.

Table 7. Results of the questionnaire the ability to used computers, smartphones, and the internet by gender

\begin{tabular}{|c|c|c|c|c|c|c|c|}
\hline \multirow{2}{*}{ Level } & \multirow{2}{*}{ Gender } & \multicolumn{2}{|c|}{ Computer } & \multicolumn{2}{|c|}{ Smartphone } & \multicolumn{2}{|c|}{ Internet } \\
\hline & & Total & $\%$ & Total & $\%$ & Total & $\%$ \\
\hline \multirow{6}{*}{ High School } & \multirow{3}{*}{ Male } & 350 & 95,63 & 82 & 93,2 & 77,03 & 84,59 \\
\hline & & 24 & 4,37 & 6 & 6,82 & 19,14 & 14,01 \\
\hline & & 0 & 0 & 0 & 0 & 3,83 & 1,40 \\
\hline & \multirow{3}{*}{ Female } & 481 & 86,51 & 123 & 87,9 & 61,65 & 71,93 \\
\hline & & 111 & 13,31 & 16 & 11,4 & 33,83 & 26,32 \\
\hline & & 3 & 0,18 & 1 & 0,71 & 4,51 & 1,75 \\
\hline \multirow{6}{*}{$\begin{array}{l}\text { Middle } \\
\text { School }\end{array}$} & \multirow{3}{*}{ Male } & 143 & 88,82 & 38 & 95 & 74,74 & 82,72 \\
\hline & & 27 & 11,18 & 2 & 5 & 21,58 & 15,92 \\
\hline & & 0 & 0 & 0 & 0 & 3,68 & 1,36 \\
\hline & \multirow{3}{*}{ Female } & 314 & 81,28 & 79 & 79 & 60,21 & 70,85 \\
\hline & & 106 & 18,29 & 21 & 21 & 34,53 & 27,09 \\
\hline & & 5 & 0,43 & 0 & 0 & 5,26 & 2,06 \\
\hline
\end{tabular}

In Table 7, it can be seen that the best ability of the male mathematics teachers in high school was using a computer ability (95.63), but not much different from their ability in using smartphones (93.2) and the internet (84.59). The best ability of male mathematics teachers in school is the ability to use smartphones (95), followed by the ability to use a computer (88.82) and the internet (82.72). The best ability of the female mathematics teachers in senior high school was to use smartphones (87.9), followed by their ability in using computers (86.51) and the internet (71.93). At the same time, the best ability of female mathematics teachers in junior high school was the ability to use the computer (81.28), but 
not much different from their ability in using smartphones (79) and the internet (70.85). From the data in Table 7, it can be concluded that the ability of mathematics teachers to use smartphones and computers was better than using the internet. To find out the significant differences between the ability to use computers, smartphones, and the internet between the male and female teachers, and Anova 2-path test was conducted, the results of which were presented in Table 8 below.

Table 8. 2-way Anova Test Results

\begin{tabular}{lrrrrr}
\hline Source & $\begin{array}{c}\text { Type III Sum of } \\
\text { Squares }\end{array}$ & Df & Mean Square & F & \multicolumn{1}{c}{ Sig. } \\
\hline Corrected Model & $785,740^{\mathrm{a}}$ & 3 & 261,913 & 2,513 &, 064 \\
Intercept & 900888,787 & 1 & 900888,787 & 8644,621 &, 000 \\
Gender & 584,576 & 1 & 584,576 & 5,609 &, 020 \\
Jenjang & 74,215 & 1 & 74,215 &, 712 &, 401 \\
Gender * Jenjang &, 042 & 1 &, 042 &, 000 &, 984 \\
Error & 9170,815 & 88 & 104,214 & & \\
Total & 1106281,000 & 92 & & & \\
Corrected Total & 9956,554 & 91 & & & \\
\hline
\end{tabular}

a. R Squared $=, 079$ (Adjusted R Squared $=, 048$ )

Based on Table 8, it can be seen that the Sig. Value on the line "Gender" was 0.020 smaller than the significance level (0.05), meaning that there were differences in the ability to use computers, smartphones, and the internet between male and female teachers. Viewed from the averages, it appeared that male teachers $(112,573)$ were better than female teachers $(106,980)$. Sig values on the "Level" line were 0.401 greater than 0.05 , meaning that there was no significant difference in the ability to use computers, smartphones, and the internet between mathematics teachers at the senior high school and junior high levels. While the Sig. in the line "Gender * Level" was 0.984, more significant than 0.05, meaning that there was no interaction effect between gender and education levels on the achievement of the ability in using computers, smartphones, and the internet.

\section{Discussion}

Based on the above research results, the first conclusion is that the ability of mathematics teachers to use computers, smartphones, and the internet has supported the application of technology-based learning in mathematics learning. The average teacher's ability in the good category was very high, almost all of which were above $80 \%$. This happens because the use of ICT in daily life has become familiar; almost all mathematics teachers have smartphones and laptops; they are also accustomed to using the internet (Asmaranti \& Andayani, 2018; Supianti et al., 2018b, 2018a). In its implementation, the use 
of ICT in learning must be the supervision and guidance of teachers to support students in obtaining and investigating ideas about mathematical concepts (Umbara, Munir, Susilana, \& Puadi, 2019).

In the second conclusion, there were differences in using computers, smartphones, and the internet among the $\mathrm{X}, \mathrm{Y}$, and $\mathrm{Z}$ generation of mathematics teachers. The ability to use the computer, smartphone and the internet of the generation $\mathrm{X}$ mathematics teachers was significantly different from the $\mathrm{Y}$ and $\mathrm{Z}$ generation teachers; the ability to use computers, smartphones, and the internet of the mathematics teachers of $\mathrm{Y}$ and $\mathrm{Z} \operatorname{did}$ not $\operatorname{differ}$ significantly. The ability to use computers, smartphones, and the internet of the $\mathrm{Y}$ and $\mathrm{Z}$ generation mathematics teachers $\mathrm{Y}$ and $\mathrm{Z}$ was better than the generation $\mathrm{X}$. This is because the $\mathrm{Y}$ and $\mathrm{Z}$ generations were more often familiar with using technology, be it computers, smartphones, or the internet. This is in line with what was stated by Perdani \& Azka (2019) that students today (millennials) tend to be more tech-savvy than the previous generation. The utilization of technology in learning mathematics in the millennial era can answer problems in conventional learning. In the end, the teachers can easily control the class, so that three is a positive impact on improving the quality of learning, which later on supports the achievement of learning objectives.

The third conclusion is that there were differences between male and female teachers in the ability to use computers, smartphones, and the internet. Male teachers were better than female teachers. The results of this study are in line with the results of Meggiolaro's research (2018), which showed that the relationship between ICT and females teachers' performance was weaker. Bagon, Gačnik, \& Starčič (2018) revealed that males used computers more often and have stronger beliefs that computer use improves student learning outcomes. Abd Rahim and Shamsiah's research (2008) in Ghavifekr \& Rosdy (2015) showed that teachers trained in Malaysia have the confidence to integrate ICT in their teaching practices and male teachers were more confident than female teachers in using ICT integration in teaching.

In the fourth conclusion, it was found that there was no significant difference in the ability to use computers, smartphones, and the internet between mathematics teachers at the senior high school and junior high school levels. As Syukur (2014) in his research on "Professionalism of Teachers in Implementing Information and Communication Technology in Nganjuk District," who's one of the aims was to examine the perceptions of elementary school teachers, junior high schools, senior high schools, and vocational high schools towards teacher professionalism in implementing the Information and Communication 
Technology to improve the quality of learning. The result was that the perception of elementary, junior high, senior high school, and vocational school teachers on teacher professionalism in implementing ICT improved the quality of learning, which was still relatively low. There was a situation similar between the technological abilities of elementary, junior high school, and vocational high school teachers.

The fifth conclusion showed that there was no interaction effect between teachers' generations and levels of education in the place of their teaching, on the achievement of the ability in using computers, smartphones, and the internet. Pedagogical content of knowledge technology, attitudes towards the use of technology in education, gender, frequency of computer use, seniority, duration of computer use, technical support, and individual innovation have direct or indirect effects on technology integration (Marbán \& Mulenga, 2019; Uslu, 2018) . Based on research by Taleb et al. (2015), based on the teacher's point of view, mobile learning had a positive effect on students' mathematics learning motivation. There was a positive and significant relationship between the use of mobile learning with student participation in learning mathematics. Similarly, the results of Alias' research (2009) showed positive student reactions to the application of technology in learning. Likewise, the results of Ruiz-Jaramillo \& Vargas-Yáñez (2018) research, found students had a positive attitude towards the use of ICT-based teaching methods and styles, causing students to become more involved and motivated. The results f Sincuba \& John's research (2017) on mobile based learning applications are very useful and effective in teaching and learning mathematics, also in increasing the students' conceptual understanding of batmobile-based, quadratic, and exponential functions

\section{CONCLUSION}

The conclusions of this study are; (1) the ability of mathematics teachers to used computers, smartphones, and the internet has supported the application of technology-based learning in mathematics learning; (2) there were differences in the ability to used computers, smartphones, and the internet among the $\mathrm{X}, \mathrm{Y}$ and $\mathrm{Z}$ generation of mathematics teachers. The ability to use a computer, smartphone, and the internet of generation $\mathrm{X}$ mathematics teachers were significantly different from the $\mathrm{Y}$ and $\mathrm{Z}$ generations. In contrast, the ability to use computers, smartphones, and internet mathematics teachers of the $\mathrm{Y}$ and $\mathrm{Z}$ generations did not differ significantly. The ability to use computers, smartphones, and the internet of the $\mathrm{Y}$ and $\mathrm{Z}$ mathematics teachers was better than Generation X; (3) there were found differences in the ability in using computers, smartphones, and the internet between male 
and female teachers. Male teachers performed better than female teachers; (4) there was no significant difference in the ability in using computers, smartphones, and the internet between mathematics teachers at the senior high school and junior high school levels; (5) there was found no interaction effect between teacher generations and levels of education, on the achievement of the ability in using computers, smartphones, and the internet.

\section{REFERENCES}

Abdussakir. (2013). Penggunaan Komputer Untuk Pembelajaran Matematika. Madrasah, 5(2), 117-133. https://doi.org/10.18860/jt.v2i2.1439

Alias, M. (2009). Integrating technology into classroom instructions for reduced misconceptions in statistics. International Electronic Journal of Mathematics Education, 4(2), 77-91.

Alkhateeb, M. A., \& Al-Duwairi, A. M. (2019). The Effect of Using Mobile Applications (GeoGebra and Sketchpad) on the Students' Achievement. International Electronic Journal of Mathematics Education, 14(3), 523-533. https://doi.org/10.29333/iejme/5754

Asmaranti, W., \& Andayani, S. (2018). Mengapa Media Berbasis Komputer dalam Pembelajaran Matematika Penting? Perspektif Guru dan Siswa. 6(2), 146-157. https://doi.org/10.21831/jpms.v6i2.23958

Bagon, Š., Gačnik, M., \& Starčič, A. I. (2018). Information communication technology use among students in inclusive classrooms. International Journal of Emerging Technologies in Learning, 13(6), 56-72. https://doi.org/10.3991/ijet.v13i06.8051

Chua, J. H., \& Jamil, H. (2014). The Effect of Field Specialization Variation on Technological Pedagogical Content Knowledge (TPACK) among Malaysian TVET Instructors. Malaysia Online Journal of Educational Technology, 2(1), 36-44.

Dirgantoro, K. P. S. (2018). Kompetensi Guru Matematika Dalam Mengembangkan Kompetensi Matematis Siswa. Scholaria: Jurnal Pendidikan Dan Kebudayaan, 8(2), 157-166. https://doi.org/10.24246/j.js.2018.v8.i2.p157-166

Drigas, A. S., \& Pappas, M. A. (2015). A review of mobile learning applications for mathematics. International Journal of Interactive Mobile Technologies, 9(3), 1823. https://doi.org/10.3991/ijim.v9i3.4420

Ghavifekr, S., \& Rosdy, W. A. W. (2015). Teaching and Learning with Technology: Effectiveness of ICT Integration in Schools. International Journal of Research in Education and Science, 1(2), 175-191. https://doi.org/10.21890/ijres.23596

Kapustina, T. V., Popyrin, A. V., \& Savina, L. N. (2015). Computer support of interdisciplinary communication of analytic geometry and algebra. International Electronic Journal of Mathematics Education, 10(3), 177-187. https://doi.org/10.12973/mathedu.2015.113a

Marbán, J. M., \& Mulenga, E. M. (2019). Pre-service Primary Teachers' Teaching Styles and Attitudes towards the Use of Technology in Mathematics Classrooms. International Electronic Journal of Mathematics Education, 14(2), 253-263. https://doi.org/10.29333/iejme/5649

Marzal, J. (2013). Pengembangan Skill dan Kompetensi TIK Guru Matematika dan IPA Kota Jambi melalui E-Tutorial Berbasis Kebutuhan Guru (Teacher's Need). TeknoPedagogi, 3(1), 28-41. https://doi.org/10.1021/cr00044a004

Meggiolaro, S. (2018). Information and communication technologies use gender and 
mathematics achievement: evidence from Italy. Social Psychology of Education, 21(2), 497-516. https://doi.org/10.1007/s11218-017-9425-7

Ozudogru, M., \& Ozudogru, F. (2019). Technological pedagogical content knowledge of mathematics teachers and the effect of demographic variables. Contemporary Educational Technology, 10(1), 1-24. https://doi.org/10.30935/cet.512515

Perdani, H. N., \& Azka, R. (2019). Teknologi dan Pembelajaran Matematika Generasi Milenial. Proseding Sendika, 5(1), 508-514.

Ruiz-Jaramillo, J., \& Vargas-Yáñez, A. (2018). Teaching structures on Architecture degrees. ICT-based methodology and teaching innovation. Revista Espanola de Pedagogia, 76(270), 353-372. https://doi.org/10.22550/REP76-2-2018-08

Salas-Rueda, R.-A. (2019). TPACK: Technological, Pedagogical and Content Model Necessary to Improve the Educational Process on Mathematics through a Web Application? International Electronic Journal of Mathematics Education, 1(1), 113. https://doi.org/10.29333/iejme/5887

Sincuba, M. C., \& John, M. (2017). An Exploration of Learners' Attitudes towards Mobile Learning Technology-Based Instruction Module and its Use in Mathematics Education. International Electronic Journal of Mathematics Education, 12(3), 845858. Retrieved from http://www.iejme.com/download/an-exploration-of-learnersattitudes-towards-mobile-learning-technology-based-instruction-module-and.pdf

Supianti, I. I. (2018). Pemanfataan Teknologi Informasi dan Komunikasi ( TIK ) dalam Pembelajaran Matematika. Mendidik: Jurnal Kajian Pendidikan Dan Pengajaran, 4(1), 63-70. https://doi.org/10.30653/003.201841.44

Supianti, I. I., Wahyudin, Kartasasmita, B. G., \& Nurlaelah, E. (2018a). Perspektif siswa atas penerapan teknologi informasi dan komunikasi (tik) dalam pembelajaran matematika. Seminar Nasional Pendidikan Matematika Dan Workshop Penyusunan Instrumen Hihg Order Thinking Skills (HOTS), (November), 124-130.

Supianti, I. I., Wahyudin, Kartasasmita, B. G., \& Nurlaelah, E. (2018b). Teachers' Perspective on The Application of Information and Communication Technology (ICT) in Mathematics Learning. Journal of Physics: Conference Series, 2019(1321), 1-5. https://doi.org/10.1088/1742-6596/1321/2/022107

Syukur, I. A. (2014). Profesionalisme Guru dalam Mengimplementasikan Teknologi Informasi dan Komunikasi di Kabupaten Nganjuk. Jurnal Pendidikan Dan Kebudayaan, 20(2), 200-2010. https://doi.org/10.24832/jpnk.v20i2.138

Taleb, Z., Ahmadi, A., \& Musavi, M. (2015). The effect of m-learning on mathematics learning. Procedia - Social and Behavioral Sciences, 171, 83-89. https://doi.org/10.1016/j.sbspro.2015.01.092

Umbara, U., Munir, M., Susilana, R., \& Puadi, E. F. W. (2019). Increase Representation in Mathematics Classes: Effects of Computer Assisted Instruction Development with Hippo Animator. International Electronic Journal of Mathematics Education, 15(2). https://doi.org/10.29333/iejme/6262

Uslu, Ö. (2018). Factors associated with technology integration to improve instructional abilities: A path model. Australian Journal of Teacher Education, 43(4), 31-50. https://doi.org/10.14221/ajte.2018v43n4.3

Valeev, A. A., Latypova, L. A., \& Latypov, N. R. (2016). The use of interactive learning technologies in teaching a foreign language in high school. Mathematics Education, 11(6), 1773-1785.

Wibowo, Wahyu; Haryatmi, Sri; Budiantara, I. N. (2009). Seminar Nasional Matematika dan Pendidikan Matematika Jurusan Pendidikan Matematika FMIPA UNY, 5 Desember 2009. Penggunaan Pembelajaran Inkuiri Dalam Mengembangkan Kemampuan Berpikir Kreatif Siswa Sma Di Kota Bengkulu, 978-979. 